UDC 821.161.1-14.09

UDC 801.82:821.161.1.02AVANGARDA

https://doi.org/10.18485/ms_zmss.2020.98.4

Ольга Соколова

Институт языкознания РАН

olga.sokolova@iling-ran.ru

Olga Sokolova

Institute of Linguistics of the RAS

olga.sokolova@iling-ran.ru

\title{
ПОЭЗИЯ, АГИТАЦИЯ И РЕКЛАМА В ХУДОЖЕСТВЕННОМ АВАНГАРДЕ 1910-х - 1920-х ГОДОВ: ЯЗЫКОВАЯ И ДИСКУРСИВНАЯ КРЕАТИВНОСТЬ ${ }^{1}$.
}

\section{POETRY, PROPAGANDA AND ADVERTISING IN THE ARTISTIC AVANT-GUARDE OF THE 1910s - 1920s: LINGUISTIC AND DISCOURSE CREATIVITY}

В статье исследуются три типа гибридных текстов 1910-х - 1920-х гг., сформированных в ситуации взаимодействия авангардного художественного, рекламного и политического дискурсов: политически «ангажированные» поэтические тексты, «агит-стихи» и «реклам-стихи». На материале исследуемых тексов выделяются два типа креативности - языковая и дискурсивная, которые имеют градуальную форму репрезентации и могут выражаться в большей или меньшей степени, как в границах отдельного дискурса, так и в зависимости от типа дискурса.

Ключевые слова: языковая и дискурсивная креативность, междискурсивное взаимодействие, авангардная поэзия, реклама, политика.

The paper analyses three types of hybrid texts of the 1910s-1920s, which resulted from the situation of interaction between the avant-garde artistic, advertising and political discourses: politically "engaged" poetic texts, "prop-poems" (propaganda poems) and "advert-poems" (advertising poems). The article reveals linguistic and discursive types of creativity, which have a gradual form of representation and can have a greater or lesser extent of expression, both within the boundaries of a specific discourse, and depending on the type of discourse.

Key words: linguistic and discursive creativity, inter-discursive reciprocity, avantgarde poetry, advertising, politics.

1 Исследование выполнено за счет гранта Российского научного фонда (проект №19-18-00040) в Институте языкознания РАН. 


\section{1. Новаторство языковое и стилевое}

Перелом в политической системе, который повлекла Октябрьская революция, оказал влияние как на социо-культурную ситуацию, так и на трансформацию языка и искусства конца 1910-1920-х гг. Эти изменения выразились в необходимости формирования концепций, построенных на сплаве радикальных идей политической и эстетической революции, поиске новых языковых и художественных средств репрезентации реальности. Основные идеи, заложенные в работах ОПОЯЗа и формалистов, концентрируются вокруг сходства и взаимодействия между поэтическим и политическим языком². Разработанные формалистами понятия «обнажения приема» (Р. Якобсон), «деавтоматизации» и «воскрешения слова» (В. Шкловский) в отношении художественного языка, получают дальнейшее развитие в статьях журнала Леф, объединивших идеи «революционизации» языка (В. Маяковский, Б. Шкловский, Р. Якобсон, Б. Эйхенбаум $)^{3}$, «охудожествления» масс (А. Луначарский) с теориями «искусства как производства» (О. Брик, Б. Арватов, Б. Кушнер) и «искусства-жизнестроения» (Н. Чужак, С. Третьяков).

«Революционизация» языка и действительности как сдвиг фокуса в формировании и восприятии текста и реальности (ср. с «деавтоматизацией», по В. Шкловскому) происходит в языке, искусстве, социуме и политике. Формирование новых связей на пересечении языка, искусства и революции приводит к повышению градуса революционности, который оказывается в состоянии постоянной динамики и выражается через метаязыковое осмысление опыта революции в работах теоретиков языка и через поиск нового языка. Во-первых, революция осмысляется как метаязыковое «обнажение прима» - несостоятельности и «автоматизации» существующего языка (как в литературе, так и в политике), неспособного оказать ни эстетического, ни перформативного воздействия на адресата. Во-вторых, происходит осознание необходимости радикального обновления языка в поэзии, политике, агитации и рекламе. Опираясь на идеи В. фон Гумбольдта, лингвисты понимают революционные изменения в языке как «творческий процесс», осуществляемый «духом народа» (Гумбольдт 1984), говоря о «прорыве словарного языкового фронта» (Горнфельд 1922: 34) и «энергичной языковой деятельности» (Селищев

2 Опоязовцы были настроены на повышение градуса революционности через синтез политических и художественных практик. В. Шкловский подчеркивал солидарность ОПОЯЗа с делом революции «Мы <ОПОЯЗ $>$ не трусы... Мы любим ветер революции» (Шкловский 1990: 310), сравнивал революцию в языке и истории с новым фокусом организации и интерпретации реальности: «Поэт снимает все вывески со своих мест, художник всегда зачинщик восстания вещей. Вещи бунтуют у поэтов, сбрасывая с себя старые имена и принимая с новым именем - новый облик» (Шкловский 1925: $61)$.

3 Осмысление проблемы языка и революции на современном этапе см. в работах (Фещенко 2018: 13-38; Калинин 2018). 
1928: 23). Революция в обыденном языке, с одной стороны, и появление новых авангардных направлений в литературе, с другой, получают развитие в работах формалистов ${ }^{4}$ : Р. О. Якобсон выделяет поэтическую функцию языка, формулируя концепцию поэтического языка как «высказывания с установкой на выражение» и на создание новой формы слова (1987), В. Б. Шкловский вводит приемы «остранения» вещей и «затрудненной формы» (1929: 13), Г. О. Винокур подчеркивает ориентированность поэзии на «языковое новаторство» (1943: 5).

Проблематизируя идею «новаторства в языке», Г. О. Винокур на материале творчества В. Маяковского разграничивает новаторство «языковое» и «стилевое». Согласно Г. О. Винокуру, стилевое новаторство это «обновление круга языковых средств, прикрепленных нормой употребления к определенному стилю речи <...> В этом случае реформируется еще не сам по себе язык, а только стиль языка, т. е. известная норма языкового употребления» (Там же: 7). Примером такого новаторства является творчество А. Пушкина. Языковым новаторством Г. Винокур обозначает «изобретение таких языковых средств, которые не даны непосредственно наличной традицией и вводятся как нечто совершенно новое в общий запас возможностей языкового выражения» (Там же: 8)5.

Развивая концепцию Г. Винокура в аспекте дискурсивного анализа, необходимо отметить специфику социо-культурной ситуации конца 1910-х — 1920-х гг., когда авангардное искусство легитимизируется и институционализируется, и авангардисты получают возможность формирования новой художественной и социальной системы советского государства. В. Беньямин определяет эти тенденции как «политизацию искусства (эстетики)» и «эстетизацию политики» (2012), а Ж. Рансьер как «перераспределения чувственного порядка», когда «искусство и политика не составляют две постоянные и отделенные друг от друга реальности», а представляют «две формы разделения чувственного, подвешенные, как одна, так и другая к специфическому режиму идентификации» (2007: 65). Взаимодействие авангардного художественного, политического и рекламного дискурсов на этом этапе можно обозначить как «контаминацию дискурсов» (лат. contaminatio - 'смешение'), что манифестируется в виде новых гибридных жанровых форм («реклам-сти-

4 Как отмечает В. В. Фещенко: «Формалистское понятие «поэтического языка», которое само было порождено авангардными экспериментами, было перенесено на обширный план фактов искусства и преобразовалось в семиотические концепции «языков искусства» и «искусства как языка» (2018: 56).

5 При этом языковое новаторство также разграничивается в случае неологизмов eуы Крученых и всехный Маяковского, где в первом случае изобретается сам «подбор звуков речи», в то время как во втором - только комбинация звукосочетаний, которые уже существуют в языке (Винокур 1943: 9-10). Далее разделяется «беспредметное» новаторство Хлебникова и новаторство Маяковского, имеющее «отчетливую стилистическую мотивировку» (Там же: 22), для которого характерно сочетание языкового новаторства со стилевым. 
хи», «агит-поэмы»), адаптации авангардных языковых приемов («остранение», словотворчество) и коммуникативных стратегий к созданию агитационных, политических и рекламных текстов (Соколова 2015: 22). Гибридные тексты характеризуются структурной гетерогенностью, преодолением внутреннего противопоставления между элементами и формированием новых свойств, возникающих в результате синтеза различных компонентов, что можно обозначить как формально-семантическую неаддитивность. Гибридные тексты формируются в зоне междискурсивного взаимодействия (в частности, авангардного художественного, peкламного и политического дискурсов), тенденция к гибридизации в них проявляется в форме языковых, жанровых, поликодовых и др. видов гибридов.

Релевантность применения дискурсивного подхода также определяется тем, что идеи формалистов, через С. Третьякова оказали влияние на Б. Брехта (который называл С. Третьякова своим учителем) и В. Беньямина, а далее - на структуралистов (Р. Барта, Ж. Деррида, Ю. Кристеву) и на М. Фуко.

Таким образом, можно переформулировать предложенную Г. О. Винокуром оппозицию как новаторство «языковое» и «дискурсивное» или, с учетом новых подходов к понятию творчества в языке 6 , как «языковую» и «дискурсивную креативность»7. Опираясь на идеи формалистов и В. П. Григорьева, определявшего поэтический язык как «язык с установкой на творчество» (2006: 233), под языковой креативностью мы понимаем создание новых, уникальных языковых единиц и модификацию отношений между ними с целью кардинальной трансформации языковой системы и формирования нового языка (ср. с «самоценным», «самовитым» словом и «заумью» в футуризме); активизацию межуровневого взаимодействия ${ }^{8}$ и контекстуально обусловленных функциональных переходов (межуровневая транспозиция и «межсемиотическая» транспозиция, по Р. Якобсону); доминирование эстетической функции, ориентированной на актуализацию означающего как направленности сообщения на собственную форму; семантическое приращение (полисемия, энантио-

6 Различные подходы и определения понятия лингвокреативность см. в (Степанов 2008; Гридина 1996; Ирисханова 2004; Демьянков 2009; Carter 2004; Langlotz 2006; Фещенко 2008; Зыкова 2015 и др.), выделение разных типов языкового творчества в (Simone 2003; Фещенко 2012; Зыкова, Киосе 2020).

7 Здесь мы не выделяем т. н. «речевую» креативность как «компетенцию», по Н. Хомскому, представляющую собой недифференцированное понимание креативности как любой речевой деятельности (Хомский 1972).

8 Межуровневое взаимодействие в авангардном поэтическом и рекламном текстах делает возможным максимальную концентрацию языковых ресурсов на минимальном вербальном пространстве. Доминантный уровень (на котором проводится эксперимент) активизирует межуровневое взаимодействие и приводит к модификации средств других уровней языка (Соколова 2015: 5-6). 
семия), сопровождающееся понижением релевантности текста и «деавтоматизацией» сознания адресата в процессе интерпретации; и метаязыковую рефлексию продуцируемых инноваций ${ }^{9}$. Под дискурсивной креативностью понимается обновление на уровне микроструктуры дискурса (в терминологии Т. ван Дейка) с помощью интенсификации тех или иных языковых приемов, апроприированных из дискурсов-«доноров» (например, межуровневая транспозиция, «межсемиотическая» транспозиция, «регулярные» неологизмы, создаваемые по известным, продуктивным моделям и используемые в утилитарных целях для обозначения новых реалий или фокусирования внимания адресата на конкретном объекте / явлении и др., - чаще всего в рекламном и политическом дискурсах), вплоть до отклонения от языковой нормы и введения «языковых аномалий», что обусловлено интенциями отправителя в актуальной коммуникативной ситуации, связанными с повышением коммуникативной эффективности сообщения, и целеполаганием на уровне макроструктуры дискурса (достижение основных целей и задач дискурса) ${ }^{10}$.

Учитывая тезис Г. О. Винокура о сочетании языкового и стилевого новаторства в поэзии Маяковского, можно отметить, что в раннем его творчестве установка на языковую креативность лежала в основании дискурсивной креативности, которая была доминирующей. Однако в творчестве 1920-х гг. эта тенденция получает дальнейшее развитие. В этот период, с одной стороны, отмечается адаптация и модификация приемов языкового творчества, разработанных в 1910-е гг., а с другой стороны, усиливается доминирование дискурсивной креативности. Это связано с активной работой Маяковского в области агитации и рекламы, что оказало влияние на его идиостиль в целом. Эта же тенденция - мотивированность языковой креативности дискурсивной креативностью отмечается и в творчестве других авторов, продолжавших авангардную традицию в 1920-е гг. (А. Крученых, Н. Асеева, В. Каменского, С. Третьякова и др.).

В творчестве Маяковского (и в разной степени в творчестве остальных перечисленных поэтов) этого периода можно выделить три типа «гибридных» текстов, сформированных на пересечении поэтического, рекламного ${ }^{11}$, агитационного и политического дискурсов. Во-первых, это «ангажированные» поэтические тексты, посвященные политической тематике (например, два «Приказа по армии искусства» (1918 и 1921),

9 О метаязыковом аспекте лингвокреативности см. (Зыкова 2017: 624; Фатеева 2017: 77).

10 О проблеме разграничения явлений лингвокреативности и стереотипности и классификации видов лингвокреативности см. (Соколова 2020).

11 Необходимо уточнить, что к рекламе в конце 1910 -х - 30-е гг. относились также агитационный и пропагандистский дискурсы. Это связано с тем, что реклама во время становления советского государства совмещала все функции - информационную, обучающую и манипулятивную. 
поэмы IV Интернационал и V Интернационал (1922), Влаgимир Ильич Ленин (1924) Маяковского; книги Железная пауза (1919), Итого (1924), поэма Буgенный (1922) Асеева; поэма Рычи, Китай (1926) Третьякова); во-вторых, агит-стихи, агит-поэмы и агитлубки (Советская азбука (1919) Маяковского и Якобсона; «Маяковская галерея» (1923), «Прошения на имя бога - в засуху не подмога» (1923) Маяковского; книга Речевик (1929) Третьякова; «Рассказ про то, как узнал Фадей закон, защищающий рабочих людей (Кодекс законов о труде)» (1923) Маяковского и Третьякова и др.); и в-третьих, реклам-стихи и реклам-поэмы для Мосполиграфа, ГУМа, Резинотреста и др.

В соответствии с пониманием лингвокреативности (или языкового творчества), сложившемся в отечественной традиции, можно говорить о том, что языковая креативность является характерной чертой художественного, и прежде всего поэтического дискурса; а также о том, что языковая и дискурсивная креативность реализуются в виде градуальных отношений - от большей степени к меньшей - в границах отдельных дискурсов и в зонах междискурсивного взаимодействия ${ }^{12}$.

Поскольку для авангардного поэтического дискурса характерна установка на создание нового языка, языковой эксперимент и «расширение словаря во всем его объеме», здесь лингвокреативность получает максимальное выражение и в языке, и в дискурсе. Что касается политического и рекламного дискурсов, то целью первого является захват и удержание власти, а второго - продажа товара и «повышение самооценки потребителя» (Эко 2004: 223) (ср. с определением рекламы как одного из двух основных «колонизирующих» типов современного дискурса - консьюмеризма и бюрократии - в классической работе Н. Фэркло Язык и власть (Fairclough 1989: 198). Соответственно, языковые модификации в этих дискурсах могут относиться к области дискурсивной креативности, и реже - к языковой, которая не относится к основным целям этих дискурсов. Исключение составляют социальная, авторская и «фестивальная» реклама, ориентированные не на продажу конкретного товара, а на изменение отношения к каким-либо социальным явлениям (подробнее о социальной рекламе и политической пропаганде см. [Эко 2004: 247, Langlotz 2015: 41-42]) или создание творческого продукта. В случае политического и рекламного типов дискурса креативность проявляется в средствах повышения эффективности коммуникации, направленных на достижение дискурсивных целей, к которым помимо словообразовательных приемов относятся также семантические (полисемия, энантиосемия) средства ${ }^{13}$.

12 О разных степенях проявления креативности и эвристичности в различных сферах коммуникации писал В. П. Григорьев (2006: 233).

13 Что касается полисемии, в коммерческой рекламе многозначность, закладываемая в высказывание для привлечения внимания адресата, снимается. Это обусловлено 
Мы уделяем особое внимание творчеству Маяковского при анализе литературы 1920-х гг. в связи с тем, что именно он совершает революционное обновление (и во много стоит у истоков формирования) рекламного и агитационного дискурсов на новом этапе их развития ${ }^{14}$. При этом в текстах Маяковского отмечается градационное изменение уровня лингвокреативности: в зависимости от формата текстов (от «ангажированных» поэтических текстов — к агит- и реклам-текстам) наблюдается понижение частотности и разнообразия инновационных языковых приемов и, соответственно, уменьшение языковой креативности.

Для выявления большей или меньшей степени лингвокреативности в художественном дискурсе обратимся для сопоставления к политическому дискурсу, примером революционизации которого являются речи В. Ленина. Вслед за К. Марксом, в последнем из «Тезисов о Фейербахе» (1845) озвучившем призыв к политическим действиям как команду, акцентируя перлокутивную функцию языка: «Философы лишь различным образом объясняли мир, но дело заключается в том, чтобы изменить его» (Маркс 1955: 4), в политике 1910-1920-х гг. формируется новый «язык революции». Такой язык направлен на активизацию механизмов, которые позволили бы изменить и обновить основы наличествующей социально-политической системы и осуществить кардинальный политический и исторический перелом.

Важно, что тогда же происходит теоретическое осмысление этого взаимодействия дискурсов в блоке статей Лефа 1924 года, посвященных проблеме формирования языка Ленина как языка революции, авторами которого стали В. Б. Шкловский, Б. М. Эйхенбаум, Л. П. Якубинский, Ю. Н. Тынянов и др. И. А. Калинин отмечает, что «описание языка Ленина как языка, в котором реализуются “открытые формалистами” законы поэтического языка, становится для опоязовцев легитимной возможностью распространить свою теорию литературной эволюции на область социальной истории в целом» (Калинин 2018: 605).

коммуникативной стратегией «целевой адресации» и дискурсивной целью (продажа конкретного товара/ услуги). В политическом дискурсе (а также в текстах политической рекламы) используется двусмысленность или двузначность (ambiguity) (cp. с тоталитарным «новоязом» Д. Оруэлла, основанном на амбивалентности и энантиосемии, когда слова имеют противоположное значение: «Война - это мир»). О двусмысленности политического дискурса пишет Н. Хомский, приводя в качестве примера «двойную» интерпретацию словосочетания rogue state: «обыденную» (идиом. 'Государство-изгой') и «пропагандистскую» (в политическом дискурсе США этим термином обозначаются страны, не находящиеся под их контролем) (Noam Chomsky 2001). Подробнее о видах полисемии в рекламном и политическом дискурсах см. в (Соколова 2020).

14 О влиянии Маяковского на формирование «революционной фразеологии» пишет Г. Винокур: «Что поэты могут во многом помочь данной области языкового строительства - сомневаться не приходится. Достаточно для этого просмотреть хотя бы агитки Маяковского» (1923a: 117). 
Одним из аспектов анализа языка Ленина с помощью арсенала средств, разработанных формалистами, становится сопоставление с художественным языком и выявление его «поэтичности» (ср. с требованием К. Маркса «поэтичности» революционного манифеста: «Социальная революция XIX века может черпать свою поэзию только из будущего, а не из прошлого» (Маркс 1961: 121)). О новой, «разрушающей», авангардной поэтичности языка Ленина пишет Б. М. Эйхенбаум: «Пафос „будничных“ слов и выражений <... является отличительной чертой его $<$ Ленина > стиля. Здесь он исторически соприкасается с тем разрушением традиционной „поэтичности“, которое отличало Толстого и которое в резкой форме явилось заново у футуристов - в частности у Маяковского» (Эйхенбаум 1924: 70). Если Г. О. Винокур называл Маяковского «новатором» языка, то В. Б. Шкловский определяет Ленина как «деканонизатора» в одноименной статье: «Ленина звали “раскалыватель", действительно, он охотно шел на раскалывание явления, на выделение его $<$... Как только слово прирастает к вещи, оно перестает ощущаться и лишается эмоционального тона» (Шкловский 1924: 53).

Таким образом, можно говорить о взаимодействии дискурсов, основанном на пересечении ключевых языковых функций: поэтической (по Р. О. Якобсону) и политической (в концепции С. Т. Золяна) как особой, дополнительной функции политического языка, заключающейся в том, что «речевой акт приведет к изменению мира, а участники этого акта наделяются соответствующей силой, но источником этой силы здесь выступает не мифология <как в случае мифологической функции прим. автора, O. С.>, а социальная структура» (Золян 2018: 31).

Рассмотрим основные типы гибридных текстов в аспекте проявления в них признаков языковой и дискурсивной креативности с учетом обращения к ведущим художественным теориям конца 1910-х — 1920-х гг.

\section{2. Политическая поэзия: языковые гибриды в области междискурсивного взаимодействия 1920-х гг.}

«Остранение» слова и вещи, «деавтоматизация», как оппозиция автоматического восприятия, выдвинутая В. Б. Шкловским, была реализована в области «обновления» словаря как реализации установки на создание нового художественного языка в авангардной литературе. Из приема авангардной литературы 1910-х гг. «остранение» становится основным принципом организации языковой, политической и социальной структуры в 1920-е гг. — как на уровне отдельного высказывания, так и на уровне формирования нового языка революции, поэзии и политики. При формировании нового языка ключевым оказывается создание новых слов. Однако, в отличие от установки Хлебникова на создание «универсального» («звездного», «вселенского») языка и эксперименты в области 
словообразования раннего авангарда, задачей поэтов конца 1910-х 1920-х гг. становится формирование «языка революции», который должен был реферировать к новым объектам действительности или новым концепциям, предлагая новые номинации для них. Таким образом, здесь словообразовательный эксперимент, относящийся к области языковой креативности, лежит в основе креативности дискурсивной, направленной на обновление политического и поэтического дискурсов и формирование новых гибридных форм междискурсивного взаимодействия (контаминация дискурсов), особенно в случае концепций «производственного искусства» или «литературы факта».

Учитывая, что многочисленные неологизмы Маяковского стали предметом разностороннего изучения ${ }^{15}$, в настоящем исследовании обратимся к анализу неологизмов, образованных в аспекте междискурсивного взаимодействия и относящихся к типу языковой гибридизации. Это такие неологизмы, компоненты которых реферируют одновременно к области языкового эксперимента и к политическим (военным) реалиям или новым социально-художественным теориям:

1) Одним из наиболее продуктивных способов образования неологизмов в политически ангажированной поэзии становятся слова-гибриды, образованные с помощью дефиса или с помощью соединительной гласной, которые реферируют, с одной стороны, к области языкового эксперимента, а с другой, к политическим (военным, революционным) или социальным реалиям.

1.1) Слова-гибриды, компоненты которых реферируют к области языкового эксперимента и к политическим (военным, революционным) реалиям: штылк-язык, мысль-красногваряейка, перелеты букв-пуль; Но мыслей ихних цела крепость, стоит, / щетинит штыки-перья; ревкультурныли; ревплаксиво; «Париж. /Фош. /Врешь, бош»/<> «Вашингтон./Закрыть Европе креgит./Предлагаем должникам торопиться со взносом». / «Москва. / А ну! / Иуи! / Сунься носом». / За раgио раяио в возgухе пляшет. / Возgух / в сплошном / и грозобуквом ералаше (Маяковский 1957, 4: 122); поэты-пистолеты (Каменский 2017: 50), футурист-песнебоец (Там же: 93), Уйти на револ-пропаганgу/За пролеткультную мирнаш /Цамбай - цамбай (Каменский 2017: 59); Язык темноустых пушек (Третьяков 2019: 74); Наgо же знать, злить, гнуть / Рельсопрокат, словонабат (Там же: 219).

Гибридные номинации регулярно создаются для обозначения новых гибридных жанров: «Аэро-пророчество», «Последняя стихобойня мо-

15 О неологизмах Маяковских см. исследования (Арватов 2020 (1931); Винокур 1943; Никульцева 2013), также они стали предметом лексикографического описания в словарях (Колесников 1991; Валавин 2010; Шестакова 2019). 
сковских футуристов» (Каменский 2017: 286), «Марш-плакат» (Третьяков 2019: 182), «МЮД-МАРШ», (Там же: 297).

1.2) Слова-гибриды, компоненты которых реферируют к области языкового эксперимента и к реалиям новых технологий и социума: словостройка взвеена (Маяковский 1957, 4: 108); Электричество/лей,/ река-лиха! /Двигай фабрики/фырком зловоgым. /Слова и слова. /Огнесловая лава (Маяковский 1958, 8: 241); Отвесна наша общая дорожка - / Певун-лифт (Третьяков 2019: 19); Панели ль кичиться вывесками, / Буквыторговки в восстанье тащая? <...> Репликой зычной вылечу/На визгоплане раяости (Там же: 127).

1.3) Слова-гибриды, компоненты которых реферируют к области языкового эксперимента и к новым социально-художественным теориям.

В 1920-е гг. идеи «остранения» и «деавтоматизации» получили развитие в концепциях «искусства как производства» и «искусства-жизнестроения». Теория «искусства-жизнестроения», «вещного» искусства и «художественно-диалектического материализма» декларировала не только стирание границ между искусством и действительностью, но и проектировала «новое искусство, которое со временем полностью утратит свою идентичность и автономность и растворится в жизни» (Заламбани 2003: 169).

Авторы этой концепции создают новые термины, относящиеся к области пересечения художественного и обыденного дискурсов, искусства и быта: «Новое искусство - я уже не раз это писал — пойдет по линии жизнестроения» (Чужак 1925б: 4); «Работники инженерийного искусства пытаются лишь сконтактировать акцент искусства с общим акцентом эпохи. Вместо искусства постных «представлений» о вещах они хотели бы побольше искусства самых всамделишных - осязаемых, слышимых, зримых, тщательно обнюхиваемых и по возможности, съедобных - вещей. Хотели бы - не одного воздействия но, по возможности, и самую вещь» (Чужак 1925а: 5). «Поэт - только словоработник и словоконструктор, мастер речековки на заводе живой жизни. Стихи - только словосплавочная лаборатория, мастерская, где гнется, режется, клепается, сваривается и свинчивается металл слова (Третьяков 2019: 691). Именно неологизмы (жизнестроение, овеществление, инженерийное искусство, словоработник, словоконструктор, мастера речековки, словосплавочная лаборатория) становятся маркерами взаимодействия искусства и производства, концептуализируя контаминацию дискурсов как на идеологическом уровне (ключевые слова), так и на структурном (гибридная форма образования неологизмов, мотивированных соединением двух слов, отсылающих к разным дискурсам).

Другие примеры неологизмов, реферирующих к новой области художественно-производственного синтеза искусства и быта, это: стихо- 
gелание; Подумай / о новом агит-винте. /Винти, / чтоб заgор не гас его. / Жgут. / Перевоgи, Коминтерн, / расовый гнев / на классовый (Маяковский 1957, 7: 61); «Гроза. (Словострунь)» (Третьяков 2019: 175); Ночью вложить gинамитный патрон / По каменный трон / Чугун-футуристов (Там же: 184); По ту сторону изображения человека-еgиницы лежат формы современной агитпластики (Пунин 1920: 2); фиксирование новых и новых моментов жизнеоборудующей изобретательности и мастерства; проф-искусство (профискусство) быто-искусство; наукизация приемов производства (Чужак 1925б: 4); вздохнули все полной футурогрудью (Каменский 2017: 57), главари-футуристы, футуро-метла (Там же: 60), Как учат футуристы / Солниевсталью / Бери верстак / И вот трудись ты Как кузнеи наg сталью - / Нау словом воли. Куй; мастерсловолейный (Там же: 62).

2) Контаминация как способ образования языковых гибридов при взаимодействии авангардного художественного и политического дискурсов.

Контаминированные слова: вольшевик, вольшь, вольшак или железовут ${ }^{16}$ (В. Хлебников); Больше паяежей / Искусственных / Умерших солни. / Больше вольши в мертвые очи. / Это узник / Узник себя, вольшевик. / ... Это вольшак / Сломал шаг (Хлебников 2001: 258). Вольшевик образовано наложением слов воля и большевик; вольшь: воля + фалшь; вольшак: воля + большак '1) Большая дорога, 2) Хозяин; старший в семье'. Важно отметить, что использование контаминации не было характерно для раннего творчества Хлебникова, максимально ориентированного на словотворчество и языковой эксперимент (ср. с заумью, внутренним склонением слов и др. авторскими способами, разработанными поэтом). Использование такого более традиционного способа как контаминация отражает изменение установки Хлебникова на языковое творчество, а также метаязыковую рефлексию языковых процессов 1920-х гг.

3) Ономатопеи, в основе которых заложены военные или урбанистические звуки.

Одним из первых прием ономатопеи использовал Ф. Т. Маринетти, обозначив его как "parole in libertà" («слова-на-свободе») и совместив в нем черты эмоционально насыщенной речи, военного репортажа и рекламного объявления: манифест «Битва вес + запах» ("Battaglia peso + odore,” 1912), книга Занг Тум Тум: битва при Аgрианополе (“Zang Tumb Tuuum: Adrianople October 1912", 1914).

16 Ср. с высказыванием Маяковского об этом неологизме Хлебникова в статье с манифестарным названием «Война и язык»: Вот почему мне ничего не говорит слово «жестокость», а «железовут» - gа. Потому что послеgнее звучит яля меня такой какофонией, какой я себе представляю войну (Маяковский 1955, 1: 327). 
Неологизмы, направленные на передачу звуков военных действий, стали частотны в авангардной литературе в годы Первой мировой войны: Зык сабли. /Ляскнула тысяча ружей (Третьяков 2019: 70); Трава - шу-шушу.../Молчать! /Шерш! / Ножи - иу-шу-шу. / Смерчь - шум (Там же: 218); Биээнзай - аль знамен./Зиээгзой - почерк клятвы. /Чичечача шашки блеск. /Бобобиба-аль окольшиа. /Мимомая-синь гусаров (Хлебников 2001: 247).

4) Неологизмы, мотивированные именами собственными политиков.

В 1920-е гг. «действовала одинаковая тенденция производить словарные новообразования от имени лиц характерных участников передаваемых в речи явлений: ленинизм, ленинец, ленинский, троцкизм, троцкист, троцкистский и др.» (Селищев 1928: 22). Такой способ словообразования оказывается продуктивным и в поэзии: Tuшь ga глаgь ga божья благоgать —/сплошное луначарство (Маяковский 1957, 7: 59); Но обер на барыню косится рабьи: / фашистский на барыне знак муссолинится (Маяковский 1957, 5: 89); И, по стопам Ллойg-Джоружиныл, гуляйте на gаче, занимайтесь мороженым (Маяковский 1957, 5: 65). Примерами таких новообразований в политическом дискурсе также являются: чемберленить, чемберлениться. - Зачем заниматься этими Чемберленами? Вот уже третье собрание на неделе и на каждом слышишь одно и то же. Да, они нам уже головы прочемберленили, а об посевной кампании ни слова! — упрекнула вдова Михалиха («Пр.» № 94. 1926). — Кто итти на выборы ленится, / Значит, тот чемберленится (плакаты, расклеенные по стенам в Москве во время выборов в Московский совет 1925 г.); Муссолинизированная Италия («Пр.» № 98. 1925)» (Цит. по: Селищев 1928: 191).

С другой стороны, новые имена образуются от новых прецедентных феноменов, среди которых особое место занимают названия социальных явлений, политических партий, временных отрезков и др., связанных с революционными событиями (например, Октябрина, Ноябрина, Инgустрина, Интерна и др.). Так, название сборника С. Третьякова Октябревичи (1924) образовано (по аналогии с другими «идеологически заряженными именами») от «названия революционного месяца-мема» (Россомахин 2019: 783): Одинаковы речи/Станка и деревни. /Mы все Октябревичи. /Mы все - Октябревны (Третьяков 2019: 186). Как отмечает А. А. Россомахин, одновременно с употреблением этого неологизма Третьяковым, он встречается и в предисловии Л. Троцкого к книге А. Безыменского Как пахнет жизнь (М., 1924): «Из всех наших поэтов, писавших о революции, для революции, по поводу революции, Безыменский наиболее органически к ней подходит, ибо он от ее плоти, сын революции, Октябревич...» (Цит. по: Россомахин 2019: 777), что отражает общую тенденцию к образованию неологизмов по сходным моделям и с учетом наиболее продуктивных способов в поэтическом и политическом дискурсах. 
В отличие от поэтических, для рекламно-агитационных текстов характерно употребление неологизмов, образованных преимущественно с целью повышения экспрессивности высказывания с помощью суффиксов субъективной оценки (аугментативы, деминутивы) и продуктивных для 1920-х гг. приставок (архи-, анти-, ультра- и др.), которые позволяют выразить градуальность (максимальную или минимальную степень) компонента значения, зависящую от фокуса восприятия отправителя. Новые слова сочетаются с научной (медицинской, технической, авиационной), религиозной или коммерческой лексикой в зависимости от формата текста (агит- или реклам-стихи).

\section{3. «Агит-стихи», «агит-поэмы» и «агитлубки»: языковые инновации на службе дискурсивной креативности}

3.1. Авиаяни и бациллина заразная: обозначение новых референтов и выражение субъективной оценки существующих объектов в агитационном дискурсе

В таких гибридных формах, как агит-стихи, агит-поэмы и агитлубки лексические инновации регулярно отсылают к новым референтам для обозначения новых индустриально-технических реалий, социальных или политических концепций. О появлении новых референтов как триггере образования новых слов писал А. Г. Горнфельд: «Новые условия разом преобразуют жизнь - поскольку она поддается преобразованию, новые понятия уже не постепенно, а сразу, массами вторгаются в жизнь, новые ощущения повелительно требуют новой формы - и новые слова, новые обороты, новые выражения неудержимым потоком низвергаются на язык» (1922: 35). (Ср. в агит-поэзии: Быт глуп. / Быт спит. / Рабклуб, / Бей быт! (Третьяков 2019: 301); Советский Союз - / Земшара шофер, / Авто и gороги / Строй Автоgор (Там же: 305); Велика Феgора, / Да не член Автоgора (Там же: 306)). Другая тенденция, характерная для агитационного и политического дискурсов, связана с появлением такого типа неологизмов, как «переименования», которые по форме относятся к неологизмам, но по содержанию описывают уже существующие явления действительности (такой тип более характерен для политического и рекламного дискурсов).

Одной из наиболее частотных становится модель образования сложных неологизмов от заимствованных корней по продуктивным русским моделям. Пропаганда авиации, связанная с необходимостью ее развития и прошедшая в 1923 г. (тогда были основаны авиакомпании «Аэрофлот» и акционерное общество добровольного воздушного флота «Добролет»), повлекла необходимость формирования нового «авиа-дискурса» и применения авангардной стратегии создания неологизмов для обозначения новых референтов. Это выразилось в повышении продуктивности нео- 
логизмов с латинским и греческим корнями авиа- (авио-), и аэро-17: авиачастушки, авиаяни (Маяковский), И гуgят во весь земной шар/Авиамари (Третьяков 2019: 317); Гляgел я на флагшток/аэроgрома, /вот и пришла аэроярема (Там же: 315); поэт-авиатор, аэро-пророчество (Каменский 2017: 10), «Лёт: Авио-стихи» (коллективный сборник, М., 1923); а также с русскими аналогами (лёт-, лет-): лётонеgеля (Маяковский 1957, 5: 85); Нам брат - летун-аппарат (Третьяков 2019: 318).

Примером употребления экспрессивно-маркированных неологизмов, направленных на реализацию прагматической интенции и привлечение внимания адресата к социальным проблемам является агит-поэма Кому и на кой ляя щеловальный обряg (1923):

\section{Шел}

через деревню

прыщщастый калека.

Калеке б этому -

нужен лекарь.

А калека фыркает:

«Поможет бог».

Остановился у образа -

и в образ чмок.

Присосался к иконе

долго и сильно.

И пока

выпячивал губищи грязные,

с губищ

на образ

вползла бациллина -

заразная,

посияела малость

и заразмножалась

(Маяковский 1957, 5: 236).

Слово бациллина, отсылающее к медицинскому дискурсу, образовано с помощью аугментативного суффикса -ин, что позволяет акцентировать ее вредоносность и осуществить сдвиг фокуса - приблизить объект (бациллу) к читателю за счет увеличения ее размеров (ср. с когнитивным механизмом «zoom in»). Использование аугментативного суф-

$17 \mathrm{Cp}$. с продуктивными моделями с корнем aero у итальянских футуристов: aeroarte, aerovita, aeropittura, aeroscrittura: «Primo dizionario aereo» (1929) Ф. Т. Маринетти и Ф. Ацари, «Manifesto dell'Aeropittura» (1931), «Manifesto dell'aeropoesia» (1931), «Aeropoema del Golfo della Spezia» и др. 
фикса -ищ при образовании слова губищи позволяет выразить не столько изменение размера, сколько маркировать разговорную речь, а также выразить субъективное отношение отправителя (пренебрежение, презрение) к самому объекту (прыщастый калека) и сформировать у адресата критическое мнение о целовальном обряде как антисанитарной процедуре. Употребление суффиксов субъективной оценки (в данном случае - аугментативных) здесь направлено не на создание новых слов, формирующих новый язык или отсылающих к новым объектам реальности, а на достижение иллокутивного эффекта и повышение прагматического воздействия на адресата (дискредитация религиозного дискурса и отказ от участия в религиозных обрядах). В неологизме заразмножалась приставка за- помимо выражения совершенного вида также маркирует дополнительное значение начала ситуации, предполагающее ее длительное разворачивание в перспективе и массовый характер вреда, который может причинить бациллина.

Таким образом, в агитационном тексте неологизмы, формируемые с помощью морфем субъективной оценки, относятся к дискурсивной креативности и направлены на достижение ключевых агитационных целей (в частности, дискредитация религиозного дискурса и ликбез в области санитарных норм среди населения).

3.2. «Обнажение» приема: метаязыковая рефлексия как основа «языка революции»

Если в раннем авангарде основными объектами метаязыковой рефлексии были проблемы языкового эксперимента и нового художественного языка, то в конце 1910-1920-х гг. в фокусе теоретиков и практиков авангардной литературы оказывается перформативный потенциал языка как способ воздействия на массового адресата. Среди основных аспектов, лежащих в основании формирования нового «языка революции» оказался заложен принцип «охудожествления» масс и создания новой коммуникативной модели «коллективного автора» и «коллективного читателя» ${ }^{18}$, преодолевающей границы между искусством и бытом, эстетической и коммуникативной функциями языка. Более того, искусство становилось тотальным проектом, направленным на строение сознания масс и социума в целом: «Искусство не только развивает наше сознание, но и организует строй наших чувств» (Калинин 1918: 9).

«Революционизация» политического дискурса строится через метаязыковое осмысление существующего, «устаревшего» языка и создание нового «языка революции». В политике наблюдается повышенное внимание к идеологической риторике и революционному языку. Анализируя

18 О коллективном искусстве см., например, (Брик 1919). 
лефовскую подборку статей о языке В. И. Ленина, И. А. Калинин отмечает, что «основным средством дезавуирования позиции идейных оппонентов служит у Ленина обнажение риторического приема, стоящего за их высказываниями» (Калинин 2018: 609). Именно такое «обнажение» ораторской несостоятельности оппонентов в форме полемики, направленной на осуждение окаменевшей «революционной фразы» как «фальшивой тени предмета», в противовес «деканонизированному», «живому» языку выявляет в языке Ленина В. Б. Шкловский: «Спор Ленина со своими противниками, будут-ли то его враги или товарищи по партии, начинается обычно со спора «о словах» - утверждения, что слова изменились» (1924: 55). Далее В. Б. Шкловский приводит несколько примеров такого осмысления Лениным новых слов: «Я бы очень хотел взять, например, несколько гострестов (если выражаться этим прекрасным русским языком, который так хвалит Тургенев) и показать, как мы умеем хозяйничать», где «ирония относится к слову “гострест”»; «Тут осталось коммунистическое чванство, комчванство, выражаясь тем же великим русским языком» (Там же). Фоносемантический анализ неологизма Антанта проводит Ю. Н. Тынянов, противопоставляя «стертое слово» союзники, в котором сохранялась возможность «оживить значение» через внутреннюю форму, новому слову Антанта, которое не только не имело такой мотивирующей основы, но «самое звуковое строение слова было несколько комическим: ан-тан; комической же была и ассоциация со словом «танта»» (1924: 101).

Как отмечают формалисты, в идиостиле Ленина происходит преодоление «окаменевшего» идеологического языка языком нового формата, в котором соединились поэтическая и политическая функции. Как пишет Б. М. Эйхенбаум, «основная стилевая тенденция Ленина - борьба с “фразами”, с “краснобайством”, с “большими словами”» (1924: 62). С другой стороны, в основе его коммуникативной стратегии лежит «деавтоматизация» слова и преодоление референциальной границы между искусством и действительностью, словом и бытом: «Его стиль состоит в снижении революционной фразы, в замене ее традиционных слов бытовым синонимом. Быт вводится Лениным для противоядия фразе, иногда для этого берется умышленно узкая тема $<\ldots>$ Он сравнивает большое с малым, пользуется примером минимальной величины, чтобы сбить слово с фальцета, расшевелить его» (Шкловский 1924: 56).

Можно привести примеры такого осмысления языковых процессов, происходящих параллельно в агитационном авангардном и политическом дискурсах, что отражает общность их интенций и реализацию междискурсивного взаимодействия. Среди основных языковых изменений того 
времени исследователи отмечают высокую продуктивность суффиксов, например -изм, «в языке революционных деятелей»19 (Селищев 1928: 22).

Метаязыковая рефлексия таких процессов выражается в лексикализации морфемы -изм(bl), которая получает у Ленина статус абстрактного существительного, обозначающего многочисленные политические партии начала XX в.: «Идейному вождю ново-искровства чудится тут “захват власти”, мерещится пугало “якобинства", “бакунизма”, “ткачевизма" и прочих странных измов» (Лен. 1905. Такт., стр. 7) (Цит. по: Селищев 1928: 182). Можно сравнить с другими политическими неологизмами: «Полититизм (голый). Правдизм ("Правда". Зиновьев. 1913. Маркс, и ликв., стр. 158). Радкизм (Радек). Революционизм (Лен. 1905. Такт., стр. 121). Стачкизм (Зиновьев. 1913. Маркс, и ликв., стр. 123). Струвизм (Лен. XV, стр. 446). Талгенизм (талант и гений. — “Вестн. Просвещ.” 1924. №2-3, 9). Тракторизм (1925). Троцкизм. Фрейдизм (взгляды Фрейда). Хвостизм (Лен. 1905. Такт., стр. 7). Царизм (Лен. 1905. Такт.; проклам., стр. 19). Центризм (“Пр.” № 93. 1925). Циммервальдизм (Лен. XV, стр. 427)» (Там же).

Продуктивные модели революционного словообразования становятся объектом рефлексии у Маяковского, что Г. О. Винокур определяет как «лингвистическую инженерию» (1923б: 208), которая в данном случае относится к области не языковой креативности, а дискурсивной, обусловленной целями массовой агитации:

Новый выпуск «истов», просто направление такое

новое, унанимистов.

Демократизмы, гуманизмы ugym u ugym за измами измьл

(Маяковский 1957, 4: 63).

Об особой «воздействующей природе языка» поэзии Маяковского пишет Б. Арватов: «Маяковский все время сознательно стремится воздействовать на слушателя, расшевелить его, растормошить, сагитировать» (2020: 131); «старается оглаголить, т. е. сделать действенным все,

19 «Речь французских и русских революционных деятелей представляет много элементов книжного, философско-теоретического происхождения. Это отражается в отдельных терминах и в образовании форм. Ср. образования с суффиксами: -isme - pyc. -изм, -iste - ист, -iser - изиро-вать, -isation - изация, -at - ат, рус. -ада (керениада, растратиада); с префиксами anti анти-, contre контр-, ultra ультра-, archi aрхи- (архитяжкий)» (Селищев 1928: 22). 
что только возможно» (Там же: 133). Такое доминирование коммуникативной функции сближает поэзию, агитацию и рекламу: «Задача агитационного ораторского языка - не доказывать, а «впечатлять, сопоставлять, вбивать в мозги, заставлять помнить»; «та же задача определяет формы плакатного и рекламного языка» (Там же: 144). О приоритете агитационной функции поэтического языка писали критики в предисловии к сборнику агитационных текстов Речевик (1929) Третьякова: «Большинство строф из Речевика мы можем написать на плакатах, на знаменах, на фанерных досках. Вознесенные над толпой, колеблемые ветром - вот где их настоящее место» (Дукор 1929: 8).

У Третьякова предметом метаязыкового осмысления становится слог ком:

Ком - итог.

Навис ком

Наg банкирьим виском -

Голос знаком.

Свист-ком.

Гуд-ком.

Рьв-ком.

Взрысв.

Ком-мунист.

Ком - сомол.

Ком-интерн

(Третьяков 2019: 308)

Ком употребляется в стихотворении в функции существительного (навис ком), как часть слова в творительном падеже (Гуg-ком./ Рыв-ком) и как субстантивированная часть корня слова коммунизм (из фр. соттипе 'община, территориальный округ' < лат. communis 'общий, всеобщий' $<\operatorname{com}(<c o n)$ 'c, вместе' + munis 'любезный, услужливый'): Ком-мунист, Ком - сомол (аббревиатура от 'коммунистический союз молодежи'), Ком - интерн (аббревиатура от 'коммунистический интернационал'). Такое осмысление словообразовательных процессов и наложение омонимов позволяет Третьякову осмыслить ключевое слово того времени (коммунизм) не только как заимствование, но и как органичный для русского языка неологизм, ставший наиболее продуктивной словообразовательной частью слова.

Таким образом, как в агитационно-поэтических, так и в политических текстах конца 1910-х - 1920-х гг. была выражена установка на междискурсивное взаимодействие и контаминацию дискурсов, что выразилось, с одной стороны, в активизации эстетической (поэтической) функции, внимании к форме высказывания и «обнажении» приема, 
а с другой, в формировании новой — политической функции языка, ориентированной на трансформацию реальности посредством повышения политической перформативности высказывания. При этом стандартизация слова или отсутствие поэтической функции при наименовании подвергалась критике (как в политических высказываниях, так и в работах по теории языка) и осмыслялась как политическое фиаско.

\section{4. «Реклам-стихи» и «реклам-поэмы»: перформативный потенциал поэтического текста}

Основным средством воздействия на адресата в рекламно-поэтических текстах, авторами которых были Маяковский, Каменский, Асеев и др. авангардисты, становится не столько формирование новых слов, сколько повышение прагматического значения высказывания и включение «межсемиотической транспозиции» (в терминологии Р. О. Якобсона), выражающейся в специальных комбинациях вербального и визуального кодов. Формирование иллокутивного эффекта достигалось за счет повышения роли прагматических средств и моделирования актуальной коммуникативной ситуации (т.н. «целевой адресации»), что позволило реализовать базовые установки на коллективное творчество и массовое воздействие, провозглашенные в работах теоретиков искусства 1920-х гг. О. Брик называл рекламу «искусством объявлять»: «Реклама не только движет коммерцию, она движет еще и культуру; она имеет громадное агитационное и культурное значение, особенно у нас в крестьянской России» (Брик 1923: 26). Маяковский подчеркивал перформативный потенциал рекламы, ассоциируя ее эффект с воздействующей силой «оружия»: «Мы знаем силу агитации... Буржуазия знает силу рекламы. Реклама - это промышленная, торговая агитация. Ни одно, даже самое верное дело не двигается без рекламы. Это оружие, поражающее конкуренцию» (Маяковский 1959, 12: 57).

Основными приемами, направленными на повышение экспрессивности и перформативности «реклам-поэзии» конца 1910-х - 1920-х гг., стали различные средства выражения субъективной модальности, «с помощью которых говорящий характеризует свое отношение к этому самому высказыванию» (Падучева 1996: 299), включая использование обращений, императивов, диалогических конструкций, вопросно-ответных структур и др.

Употребление обращений позволяет реализовать направленность рекламного сообщения на сближение адресата и адресанта, приводит к их интеграции за счет согласования точек зрения, формируя коммуникативную общность (в случае неконкретизированного обращения во множественном числе: товарищи) либо усиливая целевую адресацию и маркируя признаки группы определенных адресатов (товарищи 
gевочки, товарищи мальчики, безгалошные люgи, восточный люg, гости Батума).

Обращение также позволяет реализовать установку на активизацию параметров разговорной речи в письменном дискурсе и повысить эмоциональную наполненность сообщения, оказывая повышенное манипулятивное воздействие: Эй, товарищи, / пора вам / мерить метром, / вешать граммом. /Чтобы вы/о новых мерах/преgставление имели, /преgлагаем/ закупить немеgля/эти карамели (Маяковский 1957, 5: 301); Товарищи девочки, товарищи мальчики! / Требуйте у мамы / эти мячики (Там же: 278); Безгалошные люgи, покупайте галоши, / скияок не буgет (Там же: 277); Раgуйся, / весь восточный / люg: / привез верблюg (Там же: 282); Глаза - как море и море - как глаза. На пляже раgостных возможностей расиветает серgие и крыловейно gуша поет о весне. Слушайте, гости Батума, бирюзовый прибой волн из гряgущего (Афиша лекций Каменского в Железном театре, 1917 (Каменский 2017: 297))20.

Активизация перформативного потенциала также реализуется с помощью употребления императивных средств, формулирующих прямой призыв к действию: Беги со всех ног покупать / Огонек» (Маяковский 1957, 5: 257); Безграмотному - мучение./Купи в Госизgате книги яля учения (Там же: 265); Стой, не gыша! / В Мосполиграфе /всё-/ от гроссбуха gо карандаша (Там же: 273). Для активизации прагматической функции слова и воздействия также используются серии императивов: Стой! Прочти! Посмотри! /Выполни точка в точку./И в Моссукне, магазин № 3, оgенешься в рассрочку. / Всем коллективом обуумай gуму - кто хочет купить и на какую сумму./Выбери преgставителя (расторопного, не из разинь) и со списком желаютих пришли в магазин. / Четверть платишь наличныли, а на остальные векселя. / И ияи к прилавку, серуце веселя./И конец:: или сам забирай, или на весь коллектив вези на автомобиле! (Там же: 279).

Вопросно-ответные конструкции позволяют воспроизвести актуальную коммуникативную ситуацию и преодолеть дистанцию, характерную для письменного дискурса: Что читать труяящимся/городов и сел? / Книги «Красной нови», / в них - всё! (Там же: 258); Кодекс труgа нэпачу нипочем? / Нужен журнал - воевать с нэпачом! / Есть среgь московских журналов таковский? /Как же! Читай «Пролетарий Московский» (Там же: 259); Гgе покупали-ели самые вкусные / макароны / и вермишели? / Нигgе/кроме/как в Моссельпроме (Там же: 303).

Еще одним частотным для авангардного рекламного текста приемом является сочетание синтаксических конструкций с нулевой связкой и субстантивным предикативом с приемом межсемиотической транспо-

20 О саморекламе Каменского, Маяковского, Бурлюка и др. футуристов см. (Россомахин 2017: 280; Казакова 2019; Дядичев 2019). 


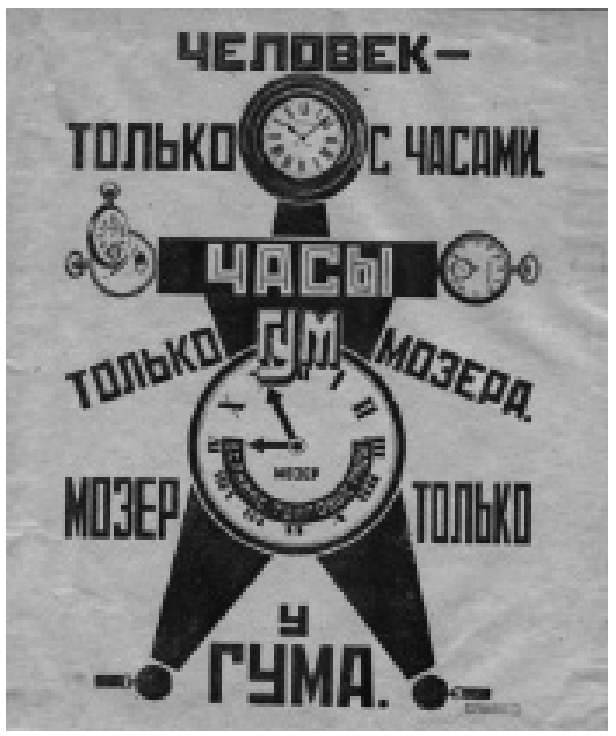

Рис. 1. В. Маяковский, А. Рояченко. Реклама часов «Мозер» (1923)

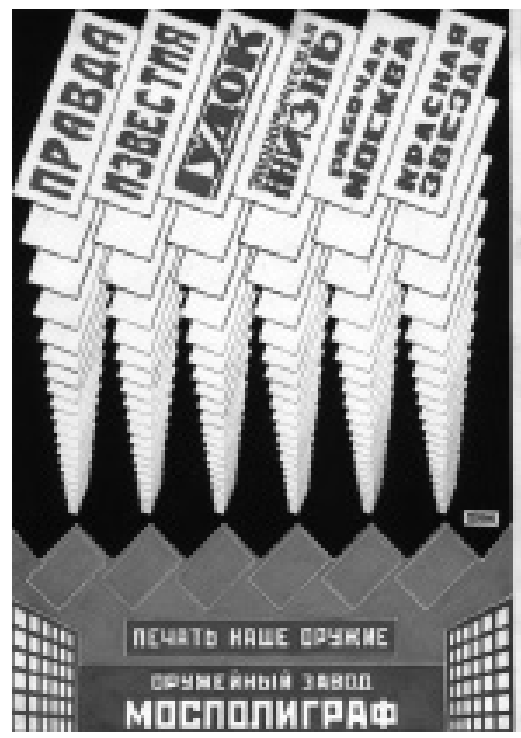

Рис. 2. В. Маяковский, А. Рояченко. Реклама для «Мосполиграфа» (1923)

зиции, что дает возможность реализовать трансфер семиотических кодов (рис. 1,2$)^{21}$.

Такая комбинация вербального и визуального кодов приводит к реализации идеи межсемиотической транспозиции Р. О. Якобсона, когда не только происходит отождествление нескольких понятий с помощью тире, но и реализуется значимая для авангардистов интенция на синтез слова и образа: Человек —/только с часами./Часы/только Мозера./ Мозер/только у ГУМа (Там же: 274); Печать — / наше оружие. / Оружейный завоg - / Мосполиграф (Там же: 272); Окрыление словотворчества. Краска - самоцель Форма музыки - gинамический шум <..> Цирк жсизни - искусство улицы - красота (Афиша лекций Каменского в Железном театре, 1917 (Каменский 297)).

Таким образом, можно выделить два вида лингвокреативности в отношении художественного дискурса: языковую и дискурсивную креативность. В 1910-е гг. происходит повышение степени языковой креативности художественного (поэтического) дискурса в силу возникновения авангардных литературных направлений, ориентированных

21 Такой взаимный перевод вербального и визуального кодов исследуется в работе Л. Алексеевой, которая отмечает, что «творческая мысль Маяковского в равной степени поддержана двумя системами знаков», когда «поэтоживопись его ранних стихов сменяют лубочные образорифмы, плакатная агитационная поэзия, затем конструктивистский дизайн рекламных текстов и книжного оформления» (Алексеева 2019: 172). 
на создание нового художественного языка. В 1920-е гг. необходимость обновления политического и рекламного дискурсов в условиях социально-политических и исторических перемен (в России, а также в ряде стран Европы, прежде всего, в Италии, Германии и Англии) приводит к их взаимодействию с авангардным художественным дискурсом. В творчестве Маяковского, Каменского, Асеева, Третьякова и др. авангардных поэтов тенденция к языковой креативности, характерная для их раннего творчества, трансформируется в направленность на дискурсивную креативность. Авангардные поэты выступают в роли «новаторов» не только поэтического, но и агитационного, рекламного и политического дискурсов. Обновление языковых средств и приемов политического и рекламного дискурсов приводит к повышению в них уровня дискурсивной лингвокреативности, который имеет градуальный характер и может варьироваться в зависимости от формата и жанра (например, авангардная, авторская и фестивальная виды рекламы обладают более высоким уровнем дискурсивной креативности, чем коммерческая). Такое влияние авангардной литературы на обновление дискурсов стало возможным в силу повышения метаязыковой рефлексии, с одной стороны, и адаптации приемов, разработанных в авангардном художественном дискурсе, к рекламному и политическому дискурсам, с другой. Это привело к осознанию языка не как инструмента, но как регулятора социальных отношений, способного инициировать исторический перелом, трансформировать общественно-политическую систему и играть ключевую роль в «жизнестроении» как творческом конструировании нового социума.

\section{ЛИТЕРАТУРА}

Алексеева Лариса. «Маяковский de visu: размышления о конфирмации образов и смыслов в иконографии поэта». Зборник майице срӣске за слависииику 95 (2019): 171-190.

Арватов Борис. О Маяковском. М.: Common place, 2020.

Беньямин Вальтер. «Произведение искусства в эпоху его технической воспроизводимости». Беньямин Вальтер. Учение о поgобии. Меgиаэстетические произвеgения. М.: РГГУ, 2012: 189-235.

Брик Осип. «Искусство объявлять (Несколько общих замечаний)». Журналист 5 (1923): $26-28$

Брик Осип. «Художник и коммуна». Изобразительное искусство 1 (1919): 25-26.

Валавин Валерий. Словотворчество Маяковского. Опыт словаря окказионализмов. М.: Азбуковник, 2010.

Василий Каменский. Поэт. Авиатор. Циркач. Гений футуризма. Неопубликованные тексты. Факсимиле. Комментарии и исслеgования / Сост. и науч. ред. Андрей Россомахин. СПб.: ЕУСПБ, 2017.

Винокур Григорий. «Революционная фразеологіия». Леф 2 (1923a): 104-118.

Винокур Григорий. «Футуристы — строители языка». Леф 1 (1923б): 204-213.

Винокур Григорий. Маяковский - новатор языка. М.: Сов. Писатель, 1943.

Горнфельд Аркадий. Новые словечки и старые слова. М., 1922. 
Григорьев Виктор. Велимир Хлебников в четырехмерном пространстве языка. Избранные работы. 1958-2000-е гоgы. М.: Языки славянских культур, 2006.

Гридина Татьяна. Языковая игра: стереотип и творчество. Екатеринбург: Урал. гос. пед. ун-т. 1996.

Гумбольдт Вильгельм фон. «О различии строения человеческих языков и его влиянии на духовное развитие человечества». Гумбольдт Вильгельм фон. Избранные труgы по языкознанию. М.: Прогресс, 1984.

Демьянков Валерий. «Языковое творчество и речевая креативность». Язык как меgиатор межgу знанием и искусством: Сборник докладов Межяународного научного семинара. М., 2009: 11-19.

Дукор Илья. «Сергей Третьяков». Третьяков Сергей. Речевик: стихи. М.: ГИЗ, 1929: 8.

Дядичев Владимир. «Маяковский, Д. Бурлюк, К. Большаков и другие... К истории Первого журнала русских футуристов». Зборник матиице срйске за славистикку 95 (2019): 237-252.

Заламбани Мария. Искусство в производстве: Авангарg и революиия в Советской России 20-х годов. Москва: ИМЛИ РАН, Наследие, 2003.

Золян Сурен. «Язык политики или язык в политической функции?». Полития 3 (2018): 31-49.

Зыкова Ирина Концептосфера культуры и фразеология: Теория и методы лингвокультурологического изучения. М., 2015.

Зыкова Ирина, Киосе Мария. «Параметризация лингвистической креативности в междискурсивном аспекте: кинодискурс vs. дискурс детской литературы». Bonpocbl когнитивной лингвистики. 2020 (в печати).

Ирисханова Ольга. Лингвокреативные основания теории номинализащии. Дис. ... докт. филол. наук. М., 2004.

Казакова Светлана. «Каменский как (само)рекламист». Василий Каменский. Поэт. Авиатор. Циркач. Гений футуризма. Неопубликованные тексты. Факсимиле. Комментарии и исслеgования / Сост. и науч. ред. Андрей Россомахин. СПб.: ЕУСПБ, 2017: 131-154.

Калинин Илья. «Как сделан язык Ленина: материал истории и прием идеологии». Becmник Санкт-Петербургского университета. Язык и литература 15 (2018): 605-617.

Калинин Федор. «Пролетариат и творчество». Пролетарская культура 1 (1918): 9.

Колесников Николай. Словарь неологизмов Маяковского. Тбилиси: Изд-во Тбилисского ун-та, 1991.

Маркс Карл. «Восемнадцатое брюмера Луи Бонапарта». Маркс Карл, Энгельс Фридрих. Сочинения в 50 mомах. Т. 8. М.: Издательство политической литературы, 1957: 115-217.

Маркс Карл. «Тезисы о Фейербахе». Маркс Карл, Энгельс Фридрих. Сочинения в 50 mомах. Т. 3. М.: Издательство политической литературы, 1955: 1-4.

Маяковский Владимир. Полное собрание сочинений: $B 13 \mathrm{~m}$. М.: Гос. изд-во худож. лит., 1955-1961. Т. 1. 1955.

Маяковский Владимир. Полное собрание сочинений: $B 13 \mathrm{~m}$. М.: Гос. изд-во худож. лит., 1955-1961. Т. 4. 1957.

Маяковский Владимир. Полное собрание сочинений: $B 13 \mathrm{~m}$. М.: Гос. изд-во худож. лит., 1955-1961. Т. 5. 1957.

Маяковский Владимир. Полное собрание сочинений: $B 13 \mathrm{~m}$. М.: Гос. изд-во худож. лит., 1955-1961. Т. 7. 1957.

Маяковский Владимир. Полное собрание сочинений: $B 13 \mathrm{~m}$. М.: Гос. изд-во худож. лит., 1955-1961. Т. 8. 1958.

Маяковский Владимир. «Агитация и реклама». Маяковский Владимир. Полное собрание сочинений: В 13 m. М.: Худож. лит., 1955-1961. Т. 12. 1959: 57-58. 
Никульцева Виктория. «Неолексикон В. Маяковского и поэтов-футуристов в сопоставительном аспекте: проблема идентичных неологизмов». Пушкинские чтения XVIII (2013): 314-321.

Падучева Елена. Семантические исслеgования. М.: Языки русской культуры, 1996.

Пунин Николай. Памятник III Интернащионала: проект художника В. Е. Татлина. Петербург: Издание отдела изобразительных искусств Н.К.П., 1920.

Рансьер Жак. Разделяя чувственное. СПб.: Изд-во ЕУСПБ, 2007.

Россомахин Андрей. «“Мастер речековки на заводе живой жизни”: Поэтические книги Сергея Третьякова». Третьяков Сергей. Итого: Собрание стихов и статей о поэзии. Сост. и примеч. Д. Карпова. М.: Рутения, 2019: 775-684.

Россомахин Андрей. «Афиши и листовки». Василий Каменский. Поэт. Авиатор. Циркач. Гений футуризма. Неопубликованные тексты. Факсимиле. Комментарии и исслеgования. Сост. и науч. ред. Андрей Россомахин. СПб.: ЕУСПБ, 2017: 280-315.

Селищев Афанасий. Язык революиионной эпохи. Из наблюgений наg русским языком послеgних лет (1917-1926). М.: Работник просвещения, 1928.

Соколова Ольга. «Дискурс-“логофаг”: границы лингвокреативности и стереотипности в рекламе». Критика и семиотика 1 (2020): 114-142.

Соколова Ольга. Дискурсы активного воздействия: теория и типология. Автореф. докт. филол. наук. М., 2015.

Степанов Юрий. «Асимптота — это стиль творчества». Творчество вне траgиционных классификаиий гуманитарных наук. М.; Калуга, 2008.

Третьяков Сергей. Итого: Собрание стихов и статей о поэзии; сост. и примеч. Д. Карпова. М.: Рутения, 2019.

Тынянов Юрий. «Словарь Ленина-полемиста». Леф 1 (1924): 81-110.

Фещенко Владимир. «Семиотика творчества и лингвистика креативности». Общественные науки и современность 6 (2008): 143-150.

Фещенко Владимир. «Язык как творчество и творчество в языке: к истории лингвистической идеи». Критика и семиотика 17 (2012): 84-94.

Фещенко Владимир. Литературный авангарg на лингвистических поворотах. СПб.: Издательство Европейского университета в Санкт-Петербурге, 2018.

Хлебников Велимир. Собрание сочинений в 6 m. Т. 2. М.: ИМЛИ РАН, 2001.

Чужак Николай. «Искусство в наши дни 2. Мост от иллюзии к материи». Жизнь искусства 25 (1925а): 5-6.

Чужак Николай. «Искусство в наши дни 3. Искусство быта». Жизнь искусства 27 (1925б): 4.

Шестакова Лариса. (отв. ред.) Словарь языка русской поэзии ХХ века. Т. VIII. М.: Издательский Дом ЯСК, 2019.

Шкловский Виктор. «Искусство как прием». Шкловский Виктор. О теории прозы. М.: Федерация, 1929: 7-23.

Шкловский Виктор. «Ленин как деканонизатор». Леф 1 (1924): 53-57.

Шкловский Виктор. Гамбургский счет: Статьи - воспоминания - эссе (1914-1933). М.: Советский писатель, 1990.

Шкловский Виктор. О теории прозы. М.; Л.: Круг, 1925.

Эко Умберто. Отсутствующая структура. Ввеgение в семиологию. М.: Symposium, 2004.

Якобсон Роман. «Новейшая русская поэзия. Набросок первый: Подступы к Хлебникову». Якобсон Роман. Работы по поэтике. М.: Прогресс, 1987: 272-316.

Carter Ronald. Language and Creativity: The Art of Common Talk. London, New York: Routledge, 2004.

Fairclough Norman. Language and Power. London, Longman, 1989.

Langlotz A. Idiomatic creativity: a cognitive-linguistic model of idiom-representation and idiom-variation in English. Amsterdam/Philadelphia: John Benjamins Publishing Company, 2006. - $340 \mathrm{p}$. 
Langlotz Andreas. "Language, creativity, and cognition from". The Routledge Handbook of Language and Creativity. Routledge, 2015: 40-60.

Noam Chomsky interviewed by Christopher Gunness, "Rogue States Draw the Usual Line," Agenda, May 2001, http://www.chomsky.info/interviews/200105--.htm.

Simone Raffaele. "Pubblicità e creatività linguistica". Il linguaggio della pubblicità. A cura di M. Baldini. Roma, 2003: 115-119.

\section{LITERATURE}

Alekseeva Larisa. «Mayakovskij de visu: razmyshleniya o konfirmacii obrazov i smyslov v ikonografii poeta». Zbornik matice srpske za slavistiku 95 (2019): 171-190.

Arvatov Boris. O Mayakovskom. M.: Common place, 2020.

Ben'yamin Val'ter. «Proizvedenie iskusstva v epohu ego tekhnicheskoj vosproizvodimosti». Ben'yamin Val'ter. Uchenie o podobii. Mediaesteticheskie proizvedeniya. M.: RGGU, 2012: 189-235.

Brik Osip. «Iskusstvo ob"yavlyat' (Neskol'ko obshchih zamechanij)». Zhurnalist 5 (1923): $26-28$.

Brik Osip. «Hudozhnik i kommuna». Izobrazitel'noe iskusstvo 1 (1919): 25-26.

Carter Ronald. Language and Creativity: The Art of Common Talk. London, New York: Routledge, 2004.

Chuzhak Nikolaj. «Iskusstvo v nashi dni 2. Most ot illyuzii k materii». Zhizn' iskusstva 25 (1925a): 5-6.

Chuzhak Nikolaj. «Iskusstvo v nashi dni 3. Iskusstvo byta». Zhizn' iskusstva 27 (1925b): 4.

Dem'yankov Valerij. «Yazykovoe tvorchestvo i rechevaya kreativnost'». Yazyk kak mediator mezhdu znaniem i iskusstvom: Sbornik dokladov Mezhdunarodnogo nauchnogo seminara. M., 2009: 11-19.

Dukor Il'ya. «Sergej Tret'yakov». Tret'yakov Sergej. Rechevik: stihi. M.: GIZ, 1929: 8.

Dyadichev Vladimir. «Mayakovskij, D. Burlyuk, K. Bol'shakov i drugie... K istorii Pervogo zhurnala russkih futuristov». Zbornik matice srpske za slavistiku 95 (2019): 237-252.

Eko Umberto. Otsutstvuyushchaya struktura. Vvedenie v semiologiyu. M.: Symposium, 2004.

Fairclough Norman. Language and Power. London, Longman, 1989.

Feshchenko Vladimir. «Semiotika tvorchestva i lingvistika kreativnosti». Obshchestvennye nauki i sovremennost' 6 (2008): 143-150.

Feshchenko Vladimir. «Yazyk kak tvorchestvo i tvorchestvo v yazyke: k istorii lingvisticheskoj idei». Kritika i semiotika 17 (2012): 84-94.

Feshchenko Vladimir. Literaturnyj avangard na lingvisticheskih povorotah. Sankt-Peterburg: Izdatel'stvo Evropejskogo universiteta v Sankt-Peterburge, 2018.

Gornfel'd Arkadij. Novye slovechki i starye slova. M., 1922.

Gridina Tat'yana. Yazykovaya igra: stereotip i tvorchestvo. Ekaterinburg: Ural. gos. ped. un-t. 1996.

Grigor'ev Viktor. Velimir Hlebnikov v chetyrekhmernom prostranstve yazyka. Izbrannye raboty. 1958-2000-e gody. M.: Yazyki slavyanskih kul'tur, 2006.

Gumbol'dt Vil'gel'm fon. «O razlichii stroeniya chelovecheskih yazykov i ego vliyanii na duhovnoe razvitie chelovechestva». Gumbol'dt Vil'gel'm fon. Izbrannye trudy po yazykoznaniyu. M.: Progress, 1984.

Iriskhanova Ol'ga. Lingvokreativnye osnovaniya teorii nominalizacii. Dis. ... dokt. filol. nauk. M.: 2004.

Hlebnikov Velimir. Sobranie sochinenij. V 6 t. T. 2. M.: IMLI RAN, 2001.

Kalinin Il'ya. «Kak sdelan yazyk Lenina: material istorii i priem ideologii». Vestnik SanktPeterburgskogo universiteta. Yazyk i literatura 15 (2018): 605-617.

Kalinin Fedor. «Proletariat i tvorchestvo». Proletarskaya kul'tura 1 (1918): 9. 
Kazakova Svetlana. «Kamenskij kak (samo)reklamist». Vasilij Kamenskij. Poet. Aviator. Cirkach. Genij futurizma. Neopublikovannye teksty. Faksimile. Kommentarii i issledovaniya. Sost. i nauch. red. Andrej Rossomahin. Sankt-Peterburg: EUSPB, 2017: 131-154.

Kolesnikov Nikolaj. Slovar' neologizmov Mayakovskogo. Tbilisi: Izd-vo Tbilisskogo un-ta, 1991.

Langlotz A. Idiomatic creativity: a cognitive-linguistic model of idiom-representation and idiom-variation in English. Amsterdam/Philadelphia: John Benjamins Publishing Company, 2006. - $340 \mathrm{p}$.

Langlotz Andreas. "Language, creativity, and cognition from". The Routledge Handbook of Language and Creativity. Routledge, 2015: 40-60.

Marks Karl. «Vosemnadcatoe bryumera Lui Bonaparta». Marks Karl, Engel's Fridrih. Sochineniya v 50 tomah. T. 8. M.: Izdatel'stvo politicheskoj literatury, 1957: 115-217.

Marks Karl. «Tezisy o Fejerbahe». Marks Karl, Engel's Fridrih. Sochineniya v 50 tomah. T. 3. M.: Izdatel'stvo politicheskoj literatury, 1955: 1-4.

Mayakovskij Vladimir. Polnoe sobranie sochinenij: V 13 t. M.: Gos. izd-vo hudozh. lit., 1955 1961. T. 1. 1955.

Mayakovskij Vladimir. Polnoe sobranie sochinenij: V 13 t. M.: Gos. izd-vo hudozh. lit., 19551961. T. 4. 1957.

Mayakovskij Vladimir. Polnoe sobranie sochinenij: V 13 t. M. Gos. izd-vo hudozh. lit., 19551961. T. 5. 1957.

Mayakovskij Vladimir. Polnoe sobranie sochinenij: V 13 t. M.: Gos. izd-vo hudozh. lit., 19551961. T. 7. 1957.

Mayakovskij Vladimir. Polnoe sobranie sochinenij: V 13 t. M.: Gos. izd-vo hudozh. lit., 19551961. T. 8. 1958.

Mayakovskij Vladimir. "Agitaciya i reklama». Mayakovskij Vladimir. Polnoe sobranie sochinenij: V 13 t. M.: Hudozh. lit., 1955-1961. T. 12. 1959: 57-58.

Nikul'ceva Viktoriya. «Neoleksikon V. Mayakovskogo i poetov-futuristov v sopostavitel'nom aspekte: problema identichnyh neologizmov». Pushkinskie chteniya XVIII (2013): 314-321.

Noam Chomsky interviewed by Christopher Gunness, "Rogue States Draw the Usual Line," Agenda, May 2001, http://www.chomsky.info/interviews/200105--.htm

Paducheva Elena. Semanticheskie issledovaniya. M.: YAzyki russkoj kul'tury, 1996.

Punin Nikolaj. Pamyatnik III Internacionala: proekt hudozhnika V. E. Tatlina. Peterburg: Izdanie otdela izobrazitel'nyh iskusstv N.K.P., 1920.

Rans'er Zhak. Razdelyaya chuvstvennoe. Sankt-Peterburg: Izd-vo EUSPB, 2007.

Rossomahin Andrej. «"Master rechekovki na zavode zhivoj zhizni”: Poeticheskie knigi Sergeya Tret'yakova». Tret'yakov Sergej. Itogo: Sobranie stihov i statej o poezii. Sost. i primech. D. Karpova. M.: Ruteniya, 2019: 775-684.

Rossomahin Andrej. «Afishi i listovki». Vasilij Kamenskij. Poet. Aviator. Cirkach. Genij futurizma. Neopublikovannye teksty. Faksimile. Kommentarii i issledovaniya. Sost. i nauch. red. Andrej Rossomahin. Sankt-Peterburg: EUSPB, 2017: 280-315.

Selishchev Afanasij. Yazyk revolyucionnoj epohi. Iz nablyudenij nad russkim yazykom poslednih let (1917-1926). M.: Rabotnik prosveshcheniya, 1928.

Shestakova Larisa. (otv. red.) Slovar' yazyka russkoj poezii XX veka. T. VIII. M.: Izdatel'skij Dom YASK, 2019.

Shklovskij Viktor. «Iskusstvo kak priem». Shklovskij Viktor. O teorii prozy. M.: Federaciya, 1929: 7-23.

Shklovskij Viktor. «Lenin kak dekanonizator». Lef 1 (1924): 53-57.

Shklovskij Viktor. Gamburgskij schet: Stat'i — vospominaniya — esse (1914-1933). M.: Sovetskij pisatel', 1990.

Shklovskij Viktor. O teorii prozy. M.; Leningrad: Krug, 1925.

Simone Raffaele. "Pubblicità e creatività linguistica". Il linguaggio della pubblicità. A cura di M. Baldini. Roma, 2003: 115-119.

Sokolova Ol'ga. «Diskurs-“logofag”: granicy lingvokreativnosti i stereotipnosti v reklame». Kritika i semiotika 1 (2020) (v pechati). 
Sokolova Ol'ga. Diskursy aktivnogo vozdejstviya: teoriya i tipologiya. Avtoref. dokt. filol. nauk. M., 2015.

Stepanov Yurij. «Asimptota — eto stil' tvorchestva». Tvorchestvo vne tradicionnyh klassifikacij gumanitarnyh nauk. M.; Kaluga, 2008.

Tret'yakov Sergej. Itogo: Sobranie stihov i statej o poezii; sost. i primech. D. Karpova. M.: Ruteniya, 2019.

Tynyanov Yurij. «Slovar» Lenina-polemista». Lef 1 (1924): 81-110.

Valavin Valerij. Slovotvorchestvo Mayakovskogo. Opyt slovarya okkazionalizmov. M.: Azbukovnik, 2010.

Vasilij Kamenskij. Poet. Aviator. Cirkach. Genij futurizma. Neopublikovannye teksty. Faksimile. Kommentarii i issledovaniya. Sost. i nauch. red. Andrej Rossomahin. SanktPeterburg: EUSPB, 2017.

Vinokur Grigorij. «Revolyucionnaya frazeologiiya». Lef 2 (1923a): 104-118.

Vinokur Grigorij. «Futuristy — stroiteli yazyka». Lef 1 (1923b): 204-213.

Vinokur Grigorij. Mayakovskij — novator yazyka. M.: Sov. Pisatel', 1943.

Yakobson Roman. «Novejshaya russkaya poeziya. Nabrosok pervyj: Podstupy k Hlebnikovu». Yakobson Roman. Raboty po poetike. M.: Progress, 1987: 272-316.

Zalambani Mariya. Iskusstvo v proizvodstve: Avangard i revolyuciya v Sovetskoj Rossii 20- $h$ godov. M.: IMLI RAN, Nasledie, 2003.

Zolyan Suren. «Yazyk politiki ili yazyk v politicheskoj funkcii?». Politiya. № 3 (2018): 31-49.

Zykova Irina Konceptosfera kul'tury i frazeologiya: Teoriya i metody lingvokul'turologicheskogo izucheniya. M., 2015.

Zykova Irina, Kiose Mariya. «Parametrizaciya lingvisticheskoj kreativnosti v mezhdiskursivnom aspekte: kinodiskurs vs. diskurs detskoj literatury». Voprosy kognitivnoj lingvistiki. 2020 (v pechati).

\section{Олга Соколова}

\section{ПОЕЗИЈА, АГИТАЦИЈА И РЕКЛАМА У УМЕТНИЧКОЈ АВАНГАРДИ 1910-1920. ГОДИНА: ЈЕЗИЧКА И ДИСКУРЗИВНА КРЕАТИВНОСТ}

\section{Резиме}

У раду се разматрају три типа хибридних текстова 1910-1920. година, који су се формирали у ситуацији узајамног утицаја авангардног уметничког, рекламног и политичког дискурса: политички „ангажована“ поезија, „агит-стихови“ и „реклама-стихови“. На материјалу текстова који се изучавају издвајају се два типа креативности — језичка и дискурзивна, које имају градуалну форму репрезентације и могу се исказивати у већој или мањој мери, како у оквирима посебног дискурса, тако и у зависности од типа дискурса.

Кључне речи: језичка и дискурзивна креативност, међудискурзивни утицај, авангардна поезија, реклама, политика. 